\title{
Habitat demands and population characteristics of the rare plant species Gladiolus imbricatus $L$. in the Frenštát region (NE Moravia, the Czech Republic)
}

Petra Kubíková \& Miroslav Zeidler

Habitat demands and population characteristics of the rare plant species Gladiolus imbricatus $L$. in the Frenštát region (NE Moravia, the Czech Republic). - Čas. Slez. Muz. Opava (A), 60: 154164, 2011.

\begin{abstract}
The sword lily (Gladiolus imbricatus L.) is an endangered species belonging to plant communities of wet meadows. Such meadows decreased in area in central Europe during the second half of the 20th century, and unsuitable biotope management has led to recent decreases in sword lily abundance. The conservation of geophytes (i.e. perennial plants with underground storage organ) like the sword lily requires knowledge of their essential environmental factors and population dynamics. Five populations of the sword lily were assessed at sites near Frenštát pod Radhoštěm (the Czech Republic). From 2008-2010 all individuals (generative, vegetative, juvenile) were counted, biometric data was measured (leaves, flowers, fruits number, and stalk height), a transient matrix was created, and vegetation (relevés) evaluated.

The number of all individuals in generative, vegetative and juvenile stage at these sites underwent year-to-year variability. Nevertheless, the influence of management practices was documented, and was also slightly reflected in both biometric parameters and population abundance. The height, number of leaves and number of blossoms did not show clear temporal or site variability. High reproductive success in this gladiolus was found (61.8-77.8\%), yet seed recruitment is crucial for population stability. In contrast to orchids, each flowering individual had a high probability of flowering to the next season (40\%) and did not switch to the dormant or vegetative stage. About $50 \%$ of individuals tended to stay in dormancy for two years. Unfortunately, the short observation period and inability to estimate the number of dormant individuals made it impossible to determine the length of dormancy, an accurate population structure, and long-term population responses to climate factors. Still, our results confirm the ecological linkage of gladiolus with a broad gradient of moisture, and their connection with mesic Arrhenatherum meadows and intermittently wet Molinia meadows. Long-term regular extensive management is essential for the persistence of populations at all study sites. Selfsowing tree species should be pruned away and herb vegetation cut down each season to provide safe sites for gladiolus seed recruitment.

Key words: sword lily, Gladiolus imbricatus L., ecobiology, population dynamics, monitoring, management
\end{abstract}

\section{Introduction}

Semi-natural wet meadows have been recognized as an important target of conservation due to their species-rich flora. The number and size of this biotope has dramatically declined in Europe during last decades of the $20^{\text {th }}$ century (Barabasz 1994, Petrríček et al. 1999, Kostrakiewicz 2007). Changes to water regimes and the absence of traditional management are considered the main reasons for the current situation (Moravec et al. 1995, Havlová 2006), and have led to composition changes in vegetation and the withdrawal or extinction of many plant species (Jongepierová 2004). One such geophyte species, the sword lily (Gladiolus imbricatus L.; Iridaceae), has withdrawn at many sites, with the absence of habitat management and successional processes mentioned as key factors (Sedláčková 1993, 2005; Hänel \& Müller 2006). In the Frenštát region, there has been a reduction in wet meadow areas and a decline in sword lily populations (Sedláčková 2005). Nevertheless, such population changes might be influenced not only by human impacts but also by species demography, the ability to colonize new areas and adaptation to environmental changes (Münzbergová 2005). In addition, longevity as an adaptation to persistence in dense vegetation can play a role (Tamm 1991). Geophytes show annual variation in the percentage of generative individuals, which is connected with intrinsic population dynamics, reproductive costs, herbivory and 

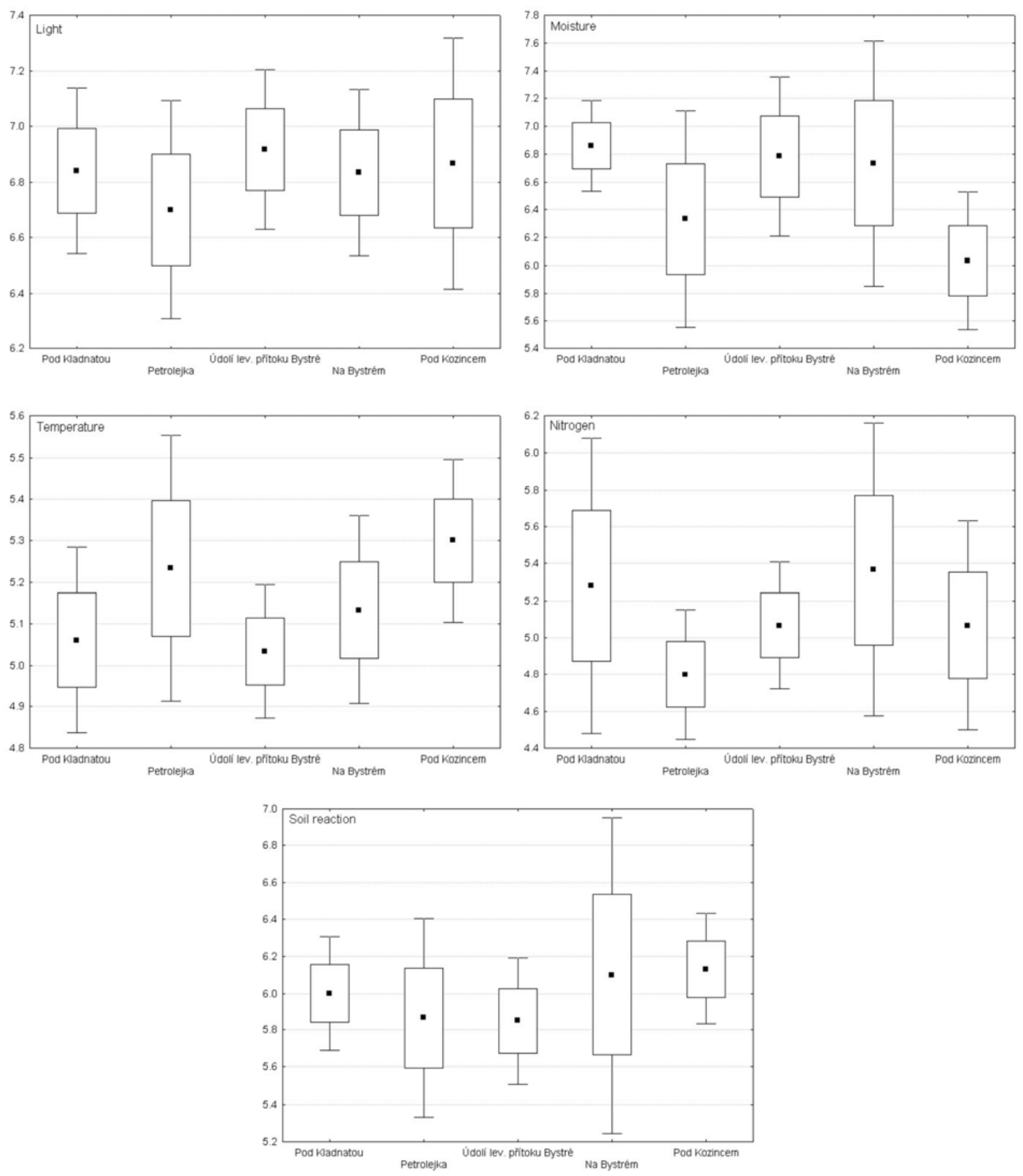

Fig. 1: Box plots with ranges of Ellenberg indicator values calculated separately on the basis of vegetation relevés for light, temperature, moisture, soil reaction, and nitrogen. The central trend (mean) and variation (standard deviations) are plotted for each group of cases.

environmental factors. None of these alone, however, unambiguously explains annual shifts from sterility or dormancy to fertility (Tamm 1991, Kindlmann \& Balounová 1999; Pfeifer et al. 2006). There have been number of studies analysing the distribution, phytosociological and habitat conditions of the sword lily in the Czech Republic (Zelená 1967; Sedláčková 1978, 2005; Barabasz 1998; Falkowski 2002; Hänel \& Müller 2006; Rombel-Bryzek 2007) but a comprehensive study focused on local reasons behind population changes is lacking.

The aim of the paper is to provide a dynamic population survey of selected sword lily populations, a measurement of the biometric parameters of individuals and a determination of the pivotal environmental factors affecting the performance of this species. Because of the 
short period of observation, the study was focused on abundance, reproductive success, and general patterns in the variation of species composition at study sites with regard to management practices.

\section{Methods}

The sword lily (Gladilolus imbricatus L.) has a corm 1-2 $\mathrm{cm}$ in diameter located approximately $10 \mathrm{~cm}$ under the surface (Moora et al. 2007). The flowering period lasts about 14 days and takes place in July - August. Sizable seeds (1.8 mg in average) mature in August-September (Zelená 1967, Goldblatt \& Manning 2008) and one individual can produce 200-400 seeds (Jogar \& Moora 2008). Seeds pass through a dormancy that is then broken during wintertime (Chrtek et al. 2007). Vegetative reproduction occurs as well, but the rate at which each reproductive method occurs is not clear (Novotná 2007). Klimeš et al. (1997) characterized the vegetative spread as limited, and the production of more than one daughter corm within one season is rare. Pollination is provided by insects, and ripened seeds undergo anemochory (Herrmann 2000, Goldblatt \& Manning 2008). Geitonogamy by means of an insect pollinator is also possible, but spontaneous autogamy is rather improbable. Autonomous apomixis has not been demonstrated (Chrtek et al. 2007).

The sword lily is native to Central and Eastern Europe, the Mediterranean, Caucasia and West Siberia (Tutin et al. 1970), and is characterized as a sub-continental species (Meusel et al. 1965). The number of local populations has decreased in the Czech Republic (Käsermann \& Moser 1999, Novotná 2007) and currently only a few local populations are known in the Frenštát region (Sedláčková 1978, 2005). It is categorised as an endangered species (C2) and protected under law in the Czech Republic (Procházka 2001).

Our experimental research was performed at five sites (Tab. 1), wet meadows in the vicinity of the municipalities Trojanovice $\left(49^{\circ} 31^{\prime} 8 " \mathrm{~N}, 18^{\circ} 14^{\prime} 25^{\prime \prime} \mathrm{E}\right)$ and Frenštát pod Radhoštěm $\left(49^{\circ} 32^{\prime 2} 22^{\prime \prime N}, 18^{\circ} 12^{\prime} 52^{\prime \prime} \mathrm{E}\right)$. The number of generative, vegetative (two and more leaves) and juvenile (one leaf) individuals was recorded at each site (see Moora et al. 2007 for details) from 2007-2010. The minimum distance between individuals was set at $5 \mathrm{~cm}$, hence an "individual" could have been composed of one or several stems (Rybka \& Novotná 2005).

The number of leaves, blossoms and capsules was recorded for each individual. The height was measured as the distance from the surface to the highest part of stem. In case of generative individuals the height included the inflorescence.

The reproduction success was computed as: $\mathrm{RS}=(\mathrm{PT} / \mathrm{PK})^{*} 100$; where $\mathrm{PT}$ is the number of capsules and PK the number of blossoms (Krátká 2006).

Plant species composition was assessed by means of 3-6 phytosociological relevés at each site. Species cover was estimated using Braun-Blanquet's seven-grade abundance-dominance scale (Kent \& Coker 1992). Nomenclature of vascular taxa followed Kubát et al. (2002) and nomenclature of vegetation syntaxa Moravec et al. (1995).

A transition matrix was calculated to express the probability of a transition among particular stages (Krátká 2006) during the vegetation seasons from 2007-2010.

Biometrical parameters collected from each site were analysed by the Kruskal-Wallis ANOVA test as nonparametric comparisons and z-values computed for each comparison $(\alpha=0.05)$ by NCSS (Hintze 2001). Phytosociological relevés were processed by Turboveg for Windows (Hennekens \& Schaminée 2001) and Ellenberg indicator values determined by JUICE 5.1 (Tichý 2002). Ellenberg indicator values (Ellenberg et al. 1992) are well established as surrogates for changes in environmental factors associated with plant communities (van der Maarel 1993).Floristic composition was analysed using CANOCO 4.5 software (ter Braak and Šmilauer 2002). We used principal component analysis (PCA) to characterise the general pattern in species composition variation, and graphical output was generated by CanoDraw for Windows 4.0 (Ter Braak \& Šmilauer 2002).

\section{Results}

The population abundance survey at individual sites revealed substantial variability among seasons. Differences in abundance were apparent especially at the site Na Bystrém, where 17 individuals were documented in 2007 and 115 individuals in the following year (Tab. 2). The population at the site Údolí levého přítoku Bystré (The valley of the left tributary of Bystrá stream) was most abundant, consisting of about 300 individuals without considerable fluctuation. In addition, individuals at this site had the highest biometric parameters number of leaves, blossoms and capsules compared with other populations (Tab. 3). On the contrary, the lowest biometric parameters were measured at the site Pod Kozincem.

Values of reproduction success differed distinctively between individuals (Tab. 4). In some individuals all capsules matured (reproduction success $100 \%$ ), whereas for some individuals in the generative stage from the same population no capsules were formed 
Tab. 1: A description of study sites surveyed.

\begin{tabular}{|c|c|c|c|}
\hline name & position [GPS; altitude] & description & management \\
\hline Pod Kozincem & $\begin{array}{l}49^{\circ} 31.485^{\prime} \mathrm{N} ; 18^{\circ} 11.620^{\prime} \mathrm{E} \\
470-480 \mathrm{~m} \text { a.s.1. }\end{array}$ & $\begin{array}{l}\text { an alluvium with sedge } \\
\text { meadows (Caricion fuscae), } \\
\text { fragments of Molinia meadows } \\
\text { (Molinion) and species of mesic } \\
\text { Arrhenatherum meadows } \\
\text { (Arrhenatherion); species of wet } \\
\text { meadows (Calthion) in terain } \\
\text { depression }\end{array}$ & $\begin{array}{l}\text { annual mowing in } \\
\text { August }\end{array}$ \\
\hline Na Bystrém & $\begin{array}{l}49^{\circ} 31.685^{\prime} \mathrm{N} ; 18^{\circ} 14.710^{\prime} \mathrm{E} \\
475 \mathrm{~m} \text { a.s.l. }\end{array}$ & $\begin{array}{l}\text { an alluvium with fragments of } \\
\text { Molinia meadows (Molinion) } \\
\text { and wet meadows (Calthion) }\end{array}$ & $\begin{array}{l}\text { annual mowing } \\
\text { resumption after } \\
\text { about a } 30 \text {-years } \\
\text { cessation }\end{array}$ \\
\hline Pod Kladnatou & $\begin{array}{l}49^{\circ} 30.833^{\prime} \mathrm{N} ; 18^{\circ} 13.175^{\prime} \mathrm{E} \\
490-500 \mathrm{~m} \text { a.s.l. }\end{array}$ & $\begin{array}{l}\text { an alluvium and adjacent } \\
\text { moderately skewed slope with } \\
\text { fragments of wet meadows } \\
\text { (Calthion) and Molinia meadows } \\
\text { (Molinion) }\end{array}$ & $\begin{array}{l}\text { management absent; } \\
\text { mowing is applied on } \\
\text { some places without } \\
\text { presence of the sword } \\
\text { lily }\end{array}$ \\
\hline Petrolejka & $\begin{array}{l}49^{\circ} 30.495^{\prime} \mathrm{N} ; 18^{\circ} 13.520^{\prime} \mathrm{E} \\
570 \mathrm{~m} \text { a.s.l. }\end{array}$ & $\begin{array}{l}\text { wet meadows (Calthion) with } \\
\text { obvious spread of early } \\
\text { successional woody species } \\
\text { (Acer pseudoplatanus) }\end{array}$ & management absent \\
\hline $\begin{array}{l}\text { Údolí levého } \\
\text { př́ítoku Bystré }\end{array}$ & $\begin{array}{l}49^{\circ} 31.306^{\prime} \mathrm{N} ; 18^{\circ} 16.050^{\prime} \mathrm{E} \\
540 \mathrm{~m} \text { a.s.1. }\end{array}$ & $\begin{array}{l}\text { meadows with plant } \\
\text { communities under impact of } \\
\text { underground water (Molinion, } \\
\text { Calthion) with early } \\
\text { successional woody species } \\
\text { (Acer pseudoplatanus, Fraxinus } \\
\text { excelsior, Tilia cordata) }\end{array}$ & management absent \\
\hline
\end{tabular}

(reproduction success $0 \%$ ). Hence, the mean value of reproduction success was $61.8 \%$ $77.78 \%$, and naturally linearly correlated with the number of blossoms (Tab. 5).

In the three years of observation, only two transitions during vegetation seasons were documented. During this time, a relatively high fraction of dormant individuals that stayed dormant in the next season were found. At the same time, individuals in the generative stage had a higher probability of staying in the generative stage in the next season (Tab. 6).

On the basis of 23 phytosociological relevés, a total of 111 vascular plant taxa were found at all sites. No significant difference in Ellenberg indicator values (EIV) among study sites was found, confirming that all study sites had similar environmental conditions (Fig. 1). There was a demand for moderate light conditions with more than $20-30 \%$ relative irradiance (EIV 6.83 $\pm 0,18$ ). Most species also require fairly warm conditions (EIV $5.15 \pm 0.17$ ), which is typical for lowland to submontane-temperate sites. Moisture characteristics (EIV $6.51 \pm 0.48$ ) reflected fresh soils of average dampness or constantly moist or damp soils. The mean value of soil reaction (EIV $5.96 \pm 0.25$ ) reflected moderate or weakly acid soils. Soils of all sites had intermediate indicator values for nitrogen availability (EIV $5.06 \pm 0.32$ ).

PCA analysis (Fig. 2) revealed a general pattern in the variation of species composition at the studied sites. The first ordination axis explained $22.4 \%$ of the total variation in species data and was associated with the soil moisture conditions irrespective of locality. The right part of the figure includes species of wet habitats or water-saturated soils like Scirpus sylvaticus, Juncus effusus, Caltha palustris, Lotus uliginosus, and Chaerophyllum hirsutum. 
Tab. 2: Number of all individuals found and their division into generative (G), vegetative (V) and juvenile (J) stages at particular sites from $2007-2010$.

\begin{tabular}{|c|c|c|c|c|c|c|c|c|c|c|}
\hline & \multicolumn{2}{|c|}{ Pod Kozincem } & \multicolumn{2}{|c|}{ Na Bystrém } & \multicolumn{2}{|c|}{ Pod Kladnatou } & \multicolumn{2}{|c|}{ Petrolejka } & \multicolumn{2}{|c|}{$\begin{array}{l}\text { Údolí levého přítoku } \\
\text { Bystré }\end{array}$} \\
\hline & $\mathrm{G} / \mathrm{V} / \mathrm{J}$ & total & $\mathrm{G} / \mathrm{V} / \mathrm{J}$ & total & $\mathrm{G} / \mathrm{V} / \mathrm{J}$ & total & $\mathrm{G} / \mathrm{V} / \mathrm{J}$ & total & $\mathrm{G} / \mathrm{V} / \mathrm{J}$ & total \\
\hline 2007 & $81 / 17 /-$ & 98 & $15 / 2 /-$ & 17 & 93/19/ - & 112 & $173 / 32 /-$ & 205 & $248 / 75 /-$ & 323 \\
\hline 2008 & $30 / 32 / 37$ & 99 & $88 / 15 / 12$ & 115 & $134 / 26 / 18$ & 178 & $96 / 32 / 34$ & 162 & $191 / 66 / 32$ & 289 \\
\hline 2009 & $46 / 17 / 21$ & 84 & $55 / 29 / 12$ & 96 & $106 / 30 / 17$ & 153 & $174 / 28 / 51$ & 253 & $194 / 65 / 23$ & 282 \\
\hline 2010 & $50 / 22 / 17$ & 89 & $67 / 19 / 13$ & 99 & $84 / 29 / 12$ & 125 & $156 / 43 / 39$ & 238 & $213 / 81 / 22$ & 316 \\
\hline
\end{tabular}

Tab. 3: Mean biometric parameters for particular sites from 2007-2010 (N - number individuals included).

\begin{tabular}{|c|c|c|c|c|c|c|c|c|c|c|}
\hline & Pod Kozincem & $\mathrm{N}$ & Na Bystrém & $\mathrm{N}$ & Pod Kladnatou & $\mathrm{N}$ & Petrolejka & $\mathrm{N}$ & $\begin{array}{l}\text { Údolí levého } \\
\text { přítoku Bystré }\end{array}$ & $\mathrm{N}$ \\
\hline stalk height & $64.581 \pm 17.448$ & 315 & $88.395 \pm 22.781$ & 387 & $85.389 \pm 21.178$ & 525 & $81.451 \pm 21.877$ & 745 & $93.027 \pm 23.373$ & 959 \\
\hline leaves number & $1.937 \pm 0.775$ & 315 & $2.426 \pm 0.822$ & 387 & $2.512 \pm 0.753$ & 525 & $2.365 \pm 0.865$ & 745 & $2.627 \pm 0.827$ & 959 \\
\hline blossoms number & $6.789 \pm 2.370$ & 128 & $9.654 \pm 2.949$ & 243 & $9.366 \pm 2.641$ & 371 & $8.554 \pm 2.707$ & 471 & $9.688 \pm 2.887$ & 641 \\
\hline capsules number & $4.508 \pm 1.687$ & 65 & $7.078 \pm 2.927$ & 243 & $6.838 \pm 2.721$ & 371 & $5.809 \pm 2.817$ & 471 & $7.073 \pm 2.971$ & 641 \\
\hline
\end{tabular}

Tab. 4: Mean reproductive success at particular sites from 2007-2010. The value for the site Pod Kozincem is missing because of mowing before capsule ripening in 2010.

\begin{tabular}{cccccc}
\hline & Pod Kozincem & Na Bystrém & Pod Kladnatou & Petrolejka & $\begin{array}{c}\text { Údolí levého } \\
\text { př́toku Bystré }\end{array}$ \\
\hline 2008 & $75.79 \pm 14.54$ & $75.05 \pm 17.35$ & $72.70 \pm 16.92$ & $61.80 \pm 21.42$ & $67.80 \pm 19.38$ \\
2009 & $71.25 \pm 18.87$ & $70.72 \pm 21.05$ & $71.19 \pm 22.46$ & $67.15 \pm 18.96$ & $77.78 \pm 17.90$ \\
2010 & - & $76.51 \pm 19.73$ & $74.00 \pm 21.58$ & $67.56 \pm 25.09$ & $70.59 \pm 23.71$ \\
\hline
\end{tabular}


Tab. 5: The correlation matrix for all study sites from $2008-2010(\mathrm{p}<0.001)$.

\begin{tabular}{lccc}
\hline & stalk height & leaves number & blossoms number \\
\hline leaves number & 0.569 & - & - \\
blossoms number & 0.539 & 0.443 & - \\
capsules number & 0.521 & 0.413 & 0.793 \\
\hline
\end{tabular}

Tab. 6: Transition matrix for all tested populations from 2008-2010 ( $\mathrm{t}-$ particular season, $\mathrm{t}+1-$ the next season)

\begin{tabular}{ccccc}
\hline & \multicolumn{3}{c}{$\mathrm{t}+1$} & \\
\cline { 2 - 4 } $\mathrm{t}$ & juvenile & generative & dormant & season \\
\hline juvenile & 0.440 & 0.240 & 0.320 & $2008 / 2009$ \\
& 0.366 & 0.287 & 0.364 & $2009 / 2010$ \\
generative & 0.240 & 0.400 & 0.360 & $2008 / 2009$ \\
& 0.169 & 0.449 & 0.382 & $2009 / 2010$ \\
dormant & - & - & - & $2008 / 2009$ \\
& 0.216 & 0.266 & 0.518 & $2009 / 2010$ \\
\hline
\end{tabular}

The opposite site of the figure contains species of drier habitats like Centaurea jacea, Succisa pratensis, Briza media, Prunella vulgaris, Phleum pratense, and Hypericum maculatum. Notably, the first axis is positively correlated with availability of nutrients, demonstrated by species like Lathyrus pratensis, Urtica dioica, Impatiens noli-tangere, Cirsium rivulare. The second ordination axis explained $12.0 \%$ of the variability and corresponded mainly to the light conditions. The bottom of the gradient includes semi-shade plants like Stachys sylvatica, Astraria major, and Deschampsia cespitosa, while and the upper includes light-loving plants like Tragopogon orientalis, Arrhenatherum elatius, Dactylis glomerata, Rumex acetosa, and Campanula patula. The position of Gladilolus imbricatus also reflects the demands of this species, being confined to intermittent moist areas with lower nutrient availability.

\section{Discussion}

Our results evaluating the eco-biological and population attributes of the sword lily in the Frenštát region were based on data from a relatively short time-period. In general, all individuals including those that are dormant should be taken into account in order to unambiguously determine such attributes. Geophytes usually undergo a dormancy period lasting for various time spans, and therefore our measurements of population abundance and other generalizations about population characteristics should be treated with caution.

Many population characteristics are connected with environmental factors; hence attention should be paid to the management of particular sites. A relatively constant number of individuals were found at the site Pod Kozincem, nevertheless the rate of juvenile/ generative/ vegetative stages varied over time. There were 81 flowering individuals in 2007 compared to 20 flowering individuals in 2005 (Sedláčková unpubl.). The higher number of juveniles is probably connected with regular annual mowing.

Twelve scattered inflorescent individuals were found at the site $\mathrm{Na}$ Bystrém in 2005 (Sedláčková 2005), much fewer than the 90 inflorescent individuals found in 1992 (Sedláčková 1993). Similarly, only 15 inflorescent individuals were recorded in 2007. The number of individuals in all stages has risen during the most recent several years, and generative individuals have become dominant. This positive trend is connected with the resumption of management (mowing) that started in 2008. A similar abrupt rise in population abundance was also documented for Dactylorhiza majalis (Janečková et al. 2006). However, 
a continual long-time data series from the site $\mathrm{Na}$ Bystrém is lacking, and thus the status in 2005 and 2007 might be exceptional.

Individuals in generative stage prevailed over vegetative and juvenile stages at the site Pod Kadnatou. The presence of this species was documented in 1982, 1992, 1997, and 2005 (Sedláčková unpubl.) but without population abundance measurements. Any estimation of population trends is therefore ambiguous because of the short time period studied.

Past information about population abundance is also missing at the site Petrolejka. The presence of Gladilolus imbricatus was confirmed at this site in 1996, 2000 (Sedláčková unpubl.), and 2005 (Sedláčková 2005). The most generative and juvenile individuals were recorded in 2009, again probably related with intervention in 2008 when a part of the meadow was mowed and the vegetation cover partly disturbed after a long period without management. An abrupt rise in juvenile sword lily individuals after a vegetation cover disturbance was also documented by Jogar \& Moora (2008) from the south-west coast of Estonia, and this phenomenon was mentioned for the geophyte Iris sibirica from south Poland (Kostrakiewicz 2007).

The most abundant population occurs at the site Údolí levého př́ítoku Bystré, estimated at about 380 individuals. Our monitoring documents a predominance of generative plants over vegetative and juvenile individuals, reflecting a declining population trend probably caused by the absence of management.

The height of individuals shows large variance because all stages (juvenile, vegetative and generative) were included. Nevertheless, the heights measured fall in the interval 55-108 cm given for the sword lily by van Raamsdonk \& de Vries (1989). Only the mean height of individuals at the site Pod Kozincem significantly differed from other sites. This was probably caused by regular mowing, as shown by Liira et al. (2009). On the contrary, the sword lily reaches greater heights on sites without regular mowing, as has also been documented for Dactylorhiza majalis (Janečková et al. 2006) and explained as a reaction to competition from the surrounding vegetation.

The mean number of leaves ranged from 1 (juvenile individuals) to 2-3 (generative individuals); individuals in the generative stage occasionally possess 4 leaves. These numbers are in accordance with other sites in the Czech Republic and central Europe (Novotná 2007, Dostál 1989, Tutin et al. 1980).

The mean number of blossoms did not show distinct variability either temporally or among sites during our observation. Commonly, one sword lily individual possesses 7-10 blossoms at our study sites, in concordance with other populations in the Czech Republic (Novotná 2007) but a broader range than generally reported (van Raamsdonk \& de Vries 1989, Horal et al. 1997, Hänel \& Müller 2006). Hänel \& Müller (2006) studied environmental factors that might influence the number of blossoms and capsules in Saxony. They deduced that dry and shady habitats reduce both the number of blossoms and capsules. Such an interaction between environmental factors and the flowering and reproduction success in the sword lily in the Czech Republic should be a topic for further study.

A high positive correlation between blossom and capsule number was demonstrated, confirming high reproduction success on average. Herrmann (2000) showed a significant correlation between number of leaves and blossom number in the related species Gladiolus palustris; however we could not confirm this relationship at our sites.

The reproduction success was $61.8 \%-77.78 \%$ at our study sites, but some individuals had $0 \%$ or $100 \%$ reproduction success values. Hänel \& Müller (2006) gave mean reproduction variability of $39 \%, 60 \%$ a $91 \%$ at three sites in Saxony, in agreement with our findings. Similar values were found for the geophyte Iris sibirica in eastern Poland (Kostrakiewicz 2007, Kostrakiewicz \& Wróblewska 2008), but a demand for open or 
disturbed sites was mentioned as a prerequisite for propagation. Hence, not only capsule number but primarily total seed number and seedling ecesis plays a key role in reproduction.

Each generative individual has a $40 \%$ probability of remaining in the generative stage for the next year at our study sites. Such notable annual variability has been confirmed in other geophytes, especially in the family Orchidaceae (Tamm 1972, Tamm 1991, Bártková \& Rybka 1999, Peintinger 2000). It is assumed that such irregularity is induced by competition, climate conditions (Tamm 1972) and the energy demands of the generative phase (Bártková \& Rybka 1999). Our results do not entirely confirm the influence of these factors, but similar obscurity was documented not only by Novotná 2007 in the sword lily, but also by Shefferson et al. (2003) in the species Cypripedium calceolus or by Hutchings (1987) in the species Ophrys sphecodes.

A specific trait of geophytes is dormancy. At our study sites, about $50 \%$ of individuals tended to stay in dormancy for two years. Novotná (2007) describes a $45 \%$ proportion of dormant sword lily individuals for some populations in the Czech Republic. Our short period of study does not provide enough data to distinguish dead and dormant individuals. Hutchings (1987) considered an individual as dead if it did not form aboveground biomass for more than three years.

The measured Ellenberg indicator values for environmental factors correspond to values found by Hänel \& Müller (2006) for their sword lily populations in Saxony. Detailed analysis revealed large variability in moisture values not only among but also within our sites, similarly as in the German study (Hänel \& Müller 2006). The sword lily prefers damp stands with less saturated soils. On the basis of the plant species recorded in phytosociological relevés, the sword lily stands belongs to mesic Arrhenatherum meadows and rudiments of intermittently wet Molinia meadows (Molinion), as shown by Moravec et al. (1995) and Chytrý et al. (2001). The sword lily occurred on constantly moist habitats together with Juncus sp., Cirsium rivulare, Equisetum sp., and Scirpus sylvaticus, but its abundance was much lower. Novotná (2007) confirmed the presence of the sword lily on other biotopes including degraded sites. The presence of species like Senecio ovatus, Cirsium palustre, Lysimachia vulgaris and Calamagrostis epigejos at some of our sites demonstrates degradation as well. The spread of the species Calamagrostis epigejos especially lowers species diversity including the sword lily (Somodi et al. 2008). Tall and perennial species overshadow and eliminate juveniles in particular (Kostrakiewicz 2007). Liira et al. (2009) demonstrated the higher occurrence of plant competitors like Calamagrostis epigejos at sites lacking management in Estonia. Early successional woody species like Acer pseudoplatanus and Fraxinus excelsior and the presence of Rubus fruticosus agg. should also be considered negatively concerning future species diversity.

Meadows as semi-natural habitat are composed of a relatively large number of plant species in a limited space, which usually causes strong competition for light, water and nutrients (Wotavová et al. 2004, Kostrakiewicz 2007). The regular removal of at least a fraction of the aboveground biomass maintains species diversity and supports poorer competitors (Jongepierová 2004). Hence, the appropriate management of habitat is crucial for the persistence of many plant species including the sword lily (Wotavová et al. 2004, Moora et al. 2007, Kostrakiewicz \& Wróblewska 2008). Yet, even a several-year absence of management may not be fatal for this species, as documented here as well as by Janečková et al. (2006). Sword lily populations usually respond to management slowly and current abundances do not necessarily reflect the potential status in the near future (Moora et al. 2007). The ecesis of the sword lily is connected with disturbances due to management or catastrophes (Janečková et al. 2006, Kostrakiewicz 2007, Moora et al. 2007, Jogar \& Moora 2008). The demographic structure of populations can be affected by different management 
practices (Kose \& Moora 2005). Thus, the future of sword lily populations at our studied sites largely depends on long-term extensive management.

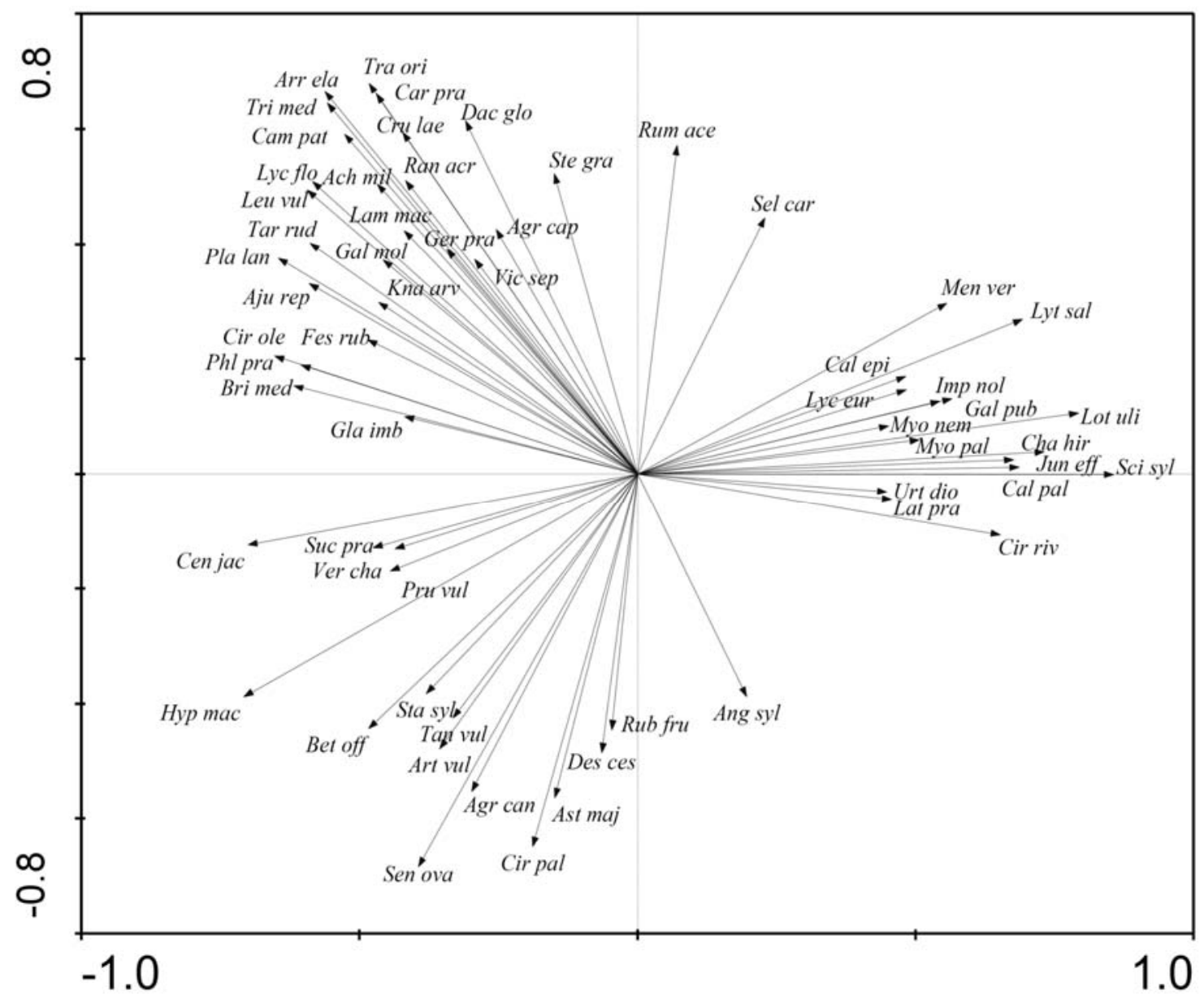

Fig. 2: Output of the PCA, with the most important species shown.

Ach mil - Achillea millefolium, Agr can - Agrostis canina, Agr cap - A. capillaris, Aju rep - Ajuga reptans, Ang syl - Angelica sylvestris, Arr ela - Arrhenatherum elatius, Art vul - Artemisia vulgaris, Ast maj - Astratia major, Bet off - Betonica officinalis, Bri med - Briza media, Cal epi-Calamagrostis epigejos, Cal pal - Caltha palustris, Cam pat - Campanula patula, Car pra - Cardamine pratensis, Cen jacCentaurea jacea, Cha hir - Chaerophyllum hirsutum, Cir ole - Cirsium oleraceum, Cir pal - C. palustre, Cir riv - C. rivulare, Cru lae Cruciata laevipes, Dac glo - Dactylis glomerata, Des ces - Deschampsia cespitosa, Fes rub - Festuca rubra, Gal mol - Galium mollugo, Gal pub - Galeopsis pubescens, Ger pra - Geranium pratense, Gla imb - Gladiolus imbricatus, Hyp mac - Hypericum maculatum, Imp nol - Impatiens noli-tangere, Jun eff - Juncus effusus, Kna arv - Knautia arvense, Lam mac - Lamium maculatum, Lat pra - Lathyrus pratensis, Leu vul - Leucanthemum vulgare, Lot uli - Lotus uliginosus, Lyc eur - Lycopus europaeus, Lyc flo - Lychnis flos-cuculi, Lyt sal - Lythrum salicaria, Men ver - Mentha x verticillata, Myo nem - Myosotis nemorosa, Myo pal - M. palustris, Phl pra - Phleum pretense, Pla lan Plantago lanceolata, Pru vul - Prunella vulgaris, Ran acr - Ranunculus acris, Rub fru - Rubus fruticosus agg., Rum ace - Rumex acetosa, Sci syl - Scirpus sylvaticus, Sel car - Selinum carvifolia, Sen ova - Senecio ovatus, Sta syl - Stachys sylvatica, Ste gra - Stellaria graminea, Suc pra - Succisa pratensis, Tan vul - Tanacetum vulgare, Tar rud - Taraxacum sect. Ruderalia, Tra ori - Tragopogon orientalis, Tri med Trifolium medium, Urt dio - Urtica dioica, Ver cha - Veronica chamaedrys, Vic sep - Vicia sepium.

\section{References}

Barabasz B. (1994): The effect of traditional management methods modifications on changes in meadows of Molinio-Arrhenatheretea. - Wiadomości Botaniczne, 38: 85-94.

- (1998): Chronione i zagrożone gatunki łąkowe w północnej części Puszczy Niepołomickiej. - Fragm. Flor. Geobot. Ser. Polonica, 5: 109-116.

Bártková R. \& Rybka V. (1999): Sledování populací vstavače trojzubého (Orchis tridentata Scop.) na Moravě. [Population monitoring of Orchis tridentata Scop. on middle Moravia (the Czech Republic)]. Př́roda, Praha, 15: 141-151.

Dostál J. (1989): Nová květena ČSSR 2. Academia, Praha, 1548 pp. 
Ellenberg H., Weber H.E., Düll R., Wirth V., Werner W. \& Paulissen D. (1992): Zeigerwerte von Pflanzen in Mitteleuropa. - Scr. Geobot., 18: 1-260.

Falkowski M. (2002): Nowe stanowisko Gladiolus imbricatus (Iridaceae) w dolinie środkowej Wisły. Fragm. Flor. Geobot. Polonica, 9: 369-370.

Goldblatt P. \& Manning J. C. (2008): The Iris family: natural history and classification. Timber Press, Portland, Oregon, $290 \mathrm{pp}$.

Havlová M. (2006): Syntaxonomical revision of the Molinion meadows in the Czech Republic. - Preslia, 78 : 87-101.

Hänel S. \& Müller F. (2006): Verbreitung, Vergesellschaftung und Ökologie der Wiesen-Siegwurz (Gladiolus imbricatus L.) in Sachsen. - Hercynia, 39:69-87.

Hennekens S.M. \& Schaminée J.H.J. (2001): Turboveg, a comprehensive data base management system for vegetation data. - J. Veg. Sci., 12: 589-591.

Herrmann N. (2000): Beiträge zur Morphologie und Biologie von Gladiolus palustris. - Schlechtendalia, 5: $19-25$.

Hintze J. (2001): NCSS and PASS. Number cruncher statistical systems., Kaysville, Utah, www.ncss.com.

Horal D., Řepka R. \& Jagoš B. (1997): Mečík bahenní (Gladiolus palustris L.) znovu v Bílých Karpatech. [Gladiolus palustris L. again in Bílé Karpaty Mts]. - Sborn. Př́r. Klubu Uherské Hradiště 2: 43-45.

Hutchings M.J. (1987): The population biology of the early spider orchid, Ophrys sphecodes Mill. II. Temporal pattern in behavior. - J. Ecol., 75: 729-742.

Chrtek J., Plačková I., Zahradníková J., Kirschner J., Kirschnerová L., Štěpánek J., Krahulcová J., Krahulec F. \& Harčarík J. (2007): Genetická variabilita vybraných horských druhů cévnatých rostlin v Krkonoších. [Genetic variability of selected vascular plant species in Giant Mts]. In Štursa J. \& Knapik R. (eds.): Geoekologické problémy Krkonoš. - Sborn. Mez. Věd. Konf. 2006, Svoboda n. Úpou. Opera Corcontica, 44/1: 251-264.

Chytrý M., Kočí M. \& Kučera T. (2001): Katalog biotopů České republiky. [Habitat catalogue of the Czech Republic]. AOPK ČR, Praha, 304 pp.

Janečková P., Wotavová K., Schödelbauerová I., Jersáková J. \& Kindlmann P. (2006): Relative effects of management and environmental conditions on performance and survival of populations of a terrestrial orchid, Dactylorhiza majalis. - Biol. Conserv., 129: 40-49.

Jogar Ü. \& Moora M. (2008): Reintroduction of a rare plant (Gladiolus imbricatus) population to a river floodplain - How important is meadow management? - Restor. Ecol., 16: 382-385.

Jongepierová I. (2008): Louky Bílých Karpat. [Meadows of Bilé Karpaty Mountains].ZO ČSOP Bílé Karpaty, Veselí nad Moravou, $461 \mathrm{pp}$.

Käsermann C. \& Moser D.M. (1999): Merkblätter Artenschutz: Blütenpflanzen und Farne, Stand: Oktober 1999 - Vollzug Umwelt / L'environnement pratique, BUWAL / OFEFP, Bern, 340 pp.

Kent M. \& Coker P. (1992): Vegetation description and analysis - a practical approach. Wiley, New York, NY, US, 363 pp.

Kindlmann P. \& Balounová Z. (1999): Flowering regimes of terrestrial orchids: unpredictability or regularity? - Journal of Vegetation Science, 10: 269-273.

Klimeš L., Klimešová J., Hendrik R. \& van Groenendael J. (1997): Clonal plant architectures: a comparative analysis of form and function, pp. 1-29. In: de Kroon H. \& van Groenendael J. (eds.): The ecology and evolution of clonal plants. Backhuys Publishers, Leiden, the Netherlands. 453 pp.

Kose M. \& Moora M. (2005): Monitoring the Wild gladiolus (Gladiolus imbricatus) population under different meadow management regimes, pp. 70-71. In: Rannap R., Briggs L., Lotman K., Lepik I. \& Rannap V. (eds.): Coastal meadow management: best practice guidelines. Ministry of the Environment of the Republic of Estonia, Tallinn, 95 pp.

Kostrakiewicz K. (2007): The effect of dominant species on numbers and age structure of Iris sibirica L. population on blue moor-grass meadow in southern Poland. - Acta. Soc. Bot. Pol., 76: 165-173.

Kostrakiewicz K. \& Wróblewska A. (2008): Low genetic variation in subpopulations of an endangered clonal plant Iris sibirica in southern Poland. - Ann. Bot. Fennici, 45: 186-194.

Krátká M. (in litt.): Populační dynamika vstavače kukačky (Orchis morio L.) na vybraných lokalitách střední Moravy. (Diplomová práce). [Population dynamics of plant species Orchis morio on selected sites of middle Moravia (the Czech Republic)]. (Diploma thesis). Faculty of Science, Palacký University in Olomouc, 2006, Olomouc, $50 \mathrm{pp}$.

Kubát K. et al. (2002): Klíč ke květeně České republiky. [Key to the flora of the Czech Republic]. Academia, Praha, 928 pp.

Liira J., Issak M., Jogar Ü., Mändoja M. \& Zobel M. (2009): Restoration management of a floodplain meadow and its cost-effectiveness - the results of a 6-year experiment. - Ann. Bot. Fenn., 46: 397-408.

Meusel H., Jäger E. \& Weinert E. (1965): Vergleichende Chronologie der Zentraleuropäischen Flora. G. Fischer, Jena, 583 pp. 
Moora M., Kose M. \& Jogar Ü. (2007): Optimal management of the rare Gladiolus imbricatus in Estonian coastal meadows indicated by its population structure. - Appl. Veg. Sci., 10:161-168.

Moravec J. et al. (1995): Rostlinná společenstva České republiky a jejich ohrožení. [Plant communities of the Czech Republic and their endangerment]. - Severočeskou př́rodou, Litoměřice, 2. Vydání, 206 pp.

Münzbergová Z. (2005): Determinants of species rarity: Population growth rates of species sharing the same habitat. - Am. J. of Bot., 92(12): 1987-1994.

Novotná P. (in litt.): Srovnání populační dynamiky Gladiolus palustris a Gladiolus imbricatus na území České republiky. (Diplomová práce). [The population-dynamic comparison of Gladiolus palustris and Gladiolus imbricatus in the Czech Republic]. (Diploma thesis). Charles University in Prague, 2007, Praha.

Peintinger M. (2000): Langfristige Veränderung der Blühhäufigkeit seltener Geophyten in Pfeifengraswiesen: zeitlicher Trend oder Einfluss von Wasserstand und Wetter? - Bauhinia, 14: 33-44.

Petříček V. et al. (1999): Péče o chráněná území I., Nelesní společenstva. [Management of protected areas I., Non-forest communities]. AOPK ČR, Praha, 456 pp.

Procházka F. (2001): Černý a červený seznam cévnatých rostlin České republiky (stav roce 2000). [Black and red list of vascular plant species of the Czech Republic]. - Příroda 18, Praha, 166 pp.

Rombel-Bryzek A. (2007): Stanowisko mieczyka dachówkowatego Gladiolus imbricatus L. w parku Krajobrazowym Chełmy na Pogórzu Kaczawskim. - Chrońmy Przyrode Ojczysta, 63: 101-105.

Rybka V. \& Novotná P. (2005): Metodika monitoringu evropsky významného druhu - mečík bahenní (Gladiolus palustris). [The monitoring methodology of European important plant species - Gladiolus palustris]. AOPK ČR, Praha, 7 pp.

Sedláčková M. (1978): Floristické poznámky k výskytu mečíku střechovitého (Gladiolus imbricatus L.) ve Frenštátské kotlině. [Floristics notes about occurrence of Gladiolus imbricatus L. on Frenštát basin]. Vlastiv. Sborn. okresu Nový Jičín, 22: 59-68.

- (1993): Př́ŕrodní památka „Louky na Bystrém“. [The natural monument „Louky na Bystrém“]. - Hlasy Muz. ve Frenštátě p. R., 10: 14-17.

- (2005): Vzácné ohrožené rostliny na Frenštátsku. [Rare and endangered plants on Frenštát region]. - Hlasy Muz. ve Frenštátě p. R., 22: 20-27.

Shefferson R.P., Proper J., Beissinger S.R. \& Simms E.L. (2003): Life histrory trade-offs in a rare orchid: The cost of flowering, dormancy, and sprouting. - Ecology, 84: 1199-1206.

Somodi I., Virágh K. \& Podani J. (2008): The effect of the expansion of the clonal grass Calamagrostis epigejos on the species turnover of a semi-arid grassland. - Appl. Veg. Sci., 11: 187-192.

Tamm C.O. (1972): Survival and flowering of some perennial herbs. II. The behaviour of some orchids on permanent plots. - Oikos, 23: 23-28.

- (1991): Behaviour of some orchid populations in a changing environment. Observations on permanent plots, 1943-1990. - Population ecology of terrestrial orchids, pp. 1-13.

- (1991): Behaviour of Some Orchid Populations in a Changing Environment: observation on Permanent Plots, 1943-1990, pp. 1-15. In Wells T.C.E. \& Willems J.H. (eds.): Population Ecology of Terrestrial Orchids. The Hague: SPB Acad. Publ., 189 pp.

ter Braak C.F.J. \& Šmilauer P. (2002): CANOCO reference manual and CanoDraw for Windows user's guide: Software for Canonical Community Ordination (vision 4.5). Microcomputer Power, Ithaca, New York, USA, 352pp.,

Tichý L. (2002): JUICE, software for vegetation analysis and classification. - J. Veg. Sci., 3: 451-453.

Tutin T.G., Heywood V.H., Burges N A., Moore D.M., Valentine E.D.H., Walters S.M. \& Webb D.A. (1980): Flora Europaea. Volume 5. Alismataceae to Orchidaceae (Monocotyledones). Cambridge University Press, $452 \mathrm{pp}$.

van der Maarel E. (1993): Relations between sociological-ecological species groups and Ellenberg indicator values. - Phytocoenologia, 23: 343-362.

van Raamsdonk L.W.D. \& de Vries T. (1989): Biosystematic Studies in European Species of Gladiolus (Iridaceae). - Plant Syst. Evol., 165: 189-98.

Wotavová K., Balounová Z. \& Kindlmann P. (2004): Factors affecting persistence of terrestrial orchids in wet meadows and implications for their conservation in a changing agricultural landscape. - Biol. Conserv., 118: 271-279.

Zelená V. (1967): Rozšíření Gladiolus imbricatus L. a Gladiolus paluster Gaud. na území Československa. [Distribution of Gladiolus imbricatus L. and Gladiolus paluster Gaud. in the Czechoslovakia]. - Acta Rer. Natur. Mus. Nat. Slov., Bratislava, 13: 19-40.

Authors' addresses: Petra Kubíková \& Miroslav Zeidler, Department of Ecology and Environmental Sciences, Faculty of Science, Palacký University, Tř. Svobody 26, CZ-771 46 Olomouc, Czech Republic, e-mail: Petra-Kaja@seznam.cz, miroslav.zeidler@upol.cz 